\title{
Origin of Dolomitization in Demirkazık Formation (Adana-Turkey)
}

\author{
Cengiz Yetiş ${ }^{1}$, Bayram Ali Mert², Meryem Yeşilot Kaplan²* \\ ${ }^{1}$ Department of Geology Engineering, Çukurova University, Adana, Turkey \\ ${ }^{2}$ Department of Petroleum and Natural Gas Engineering, İskenderun Technical University, Hatay, Turkey \\ Email: meryem.yesilotkaplan@iste.edu.tr
}

How to cite this paper: Yetiș, C., Mert, B.A. and Yeşilot Kaplan, M. (2017) Origin of Dolomitization in Demirkazık Formation (Adana-Turkey). Journal of Geoscience and Environment Protection, 5, 135-146. https://doi.org/10.4236/gep.2017.56014

Received: May 9, 2017

Accepted: June 16, 2017

Published: June 19, 2017

Copyright (c) 2017 by authors and Scientific Research Publishing Inc. This work is licensed under the Creative Commons Attribution International License (CC BY 4.0).

http://creativecommons.org/licenses/by/4.0/

(c) (i) Open Access

\begin{abstract}
Demirkazık formation consisting of the limestones and dolomites is common in the Adana, Turkey. In this study, it is aimed to find the origin of dolomitization by preparing a detailed geological map. For this purpose, firstly, thin section/polished section and, chemical analysis of the twenty-one samples characterizing dolomitization of the field were prepared and examined. In the chemical analyzes, 21 samples were determined $\mathrm{MgO}-\mathrm{CaO}$ ratio. Geological map was prepared by field study and $\mathrm{MgO}$ contents of the samples that are known coordinates in the chemical data, and the regions where dolomitization was effective were determined. Dolomitization in these carbonates occurs at early stages and late stages. Two dolomite types are petrographically determined; (1) fine crystalline dolomite (TD-1) with $10-25 \mu \mathrm{m}$ crystal size and (2) coarse crystalline dolomite (TD-2) with $50-120 \mu \mathrm{m}$ crystal size. TD-1 is formed by synsedimentary replacement and TD-2 derived from TD-1. The evidence of dolomitization due to pressure changes in the TD-2 dolomites is evidence of late diagenetic. There are three types of carbonate by chemical data; limestone, dolomitic limestone, calcitic dolomite and $\mathrm{MgCO}_{3}$ ratio of these is increased respectively. The rate of dolomitization is very variable and at the fracture regions, the $\mathrm{Mg}$ ratio increases, indicating that tectonism is the cause of dolomitization.
\end{abstract}

\section{Keywords}

Dolomite, Limestone, Replacement, Dolomitization

\section{Introduction}

Mesozoic limestones and dolomites are common in Middle \& Eastern Taurus range, northern part of Adana region and are generally distributed east of the Adana region as Misis Complex (Figure 1). The study area is located in the re- 


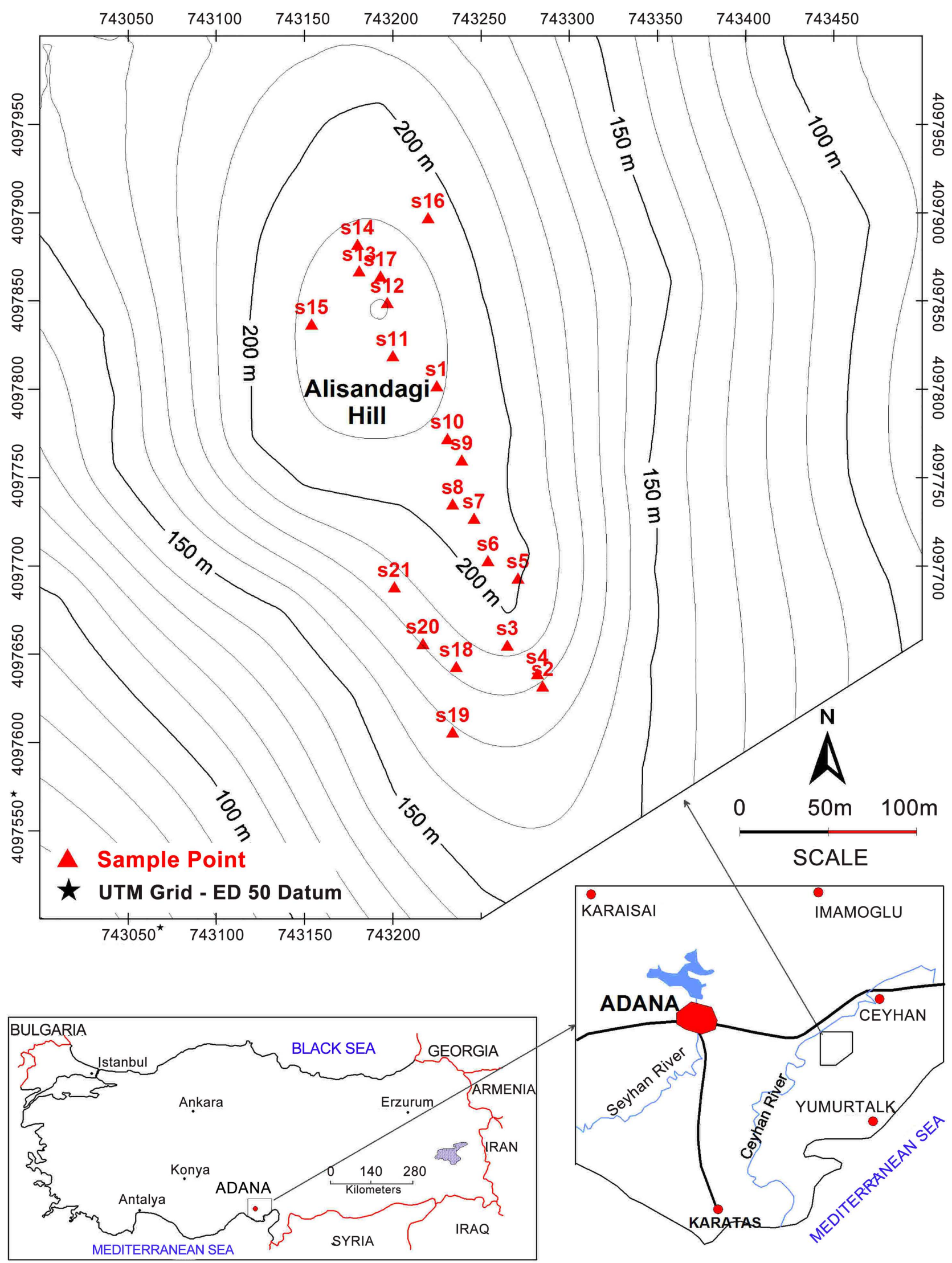

Figure 1. Location of study area. 
gion of Ceyhan (Adana) where dolomites and limestones are widespread in the Late Triassic-Cretaceous age Demirkazık formation [1] [2] [3]. The aim of this study is to examine the petrographic and geochemical features of the carbonates in the Demirkazık formation and the origin of dolomitization.

The origin of dolomitization is controversial and many models have been proposed [4] [5] [6] [7]. Dolomitization models; mixing zone dolomitization [8] [9] [10], sabhka/evaporation [11], seepage reflux [12] [13] and burial dolomitization [14] [15].

Many of the dolomites $\left(\mathrm{CaMg}\left[\mathrm{CO}_{3}\right]_{2}\right)$ are secondary origin and formed by geochemical and tectonic factors and replacement calcite $\left(\mathrm{CaCO}_{3}\right)$. Furthermore, the liquid which causes the dolomitization reactions interact with the lime deposits or pre-formed limestone. In addition, it is the interaction of lime deposits or pre-formed limestone, which causes dolomitization reactions [16] [17]. Depending on the replacement process, dolomite, dolomitic limestone and limestone are commonly present. Minor quantities are non-carbonated components; these are generally siliceous, iron-oxide and aluminum components.

Dolomite is a metastable mineral, whose early formed crystals can be replaced by later more stable phases with such replacements repeated a number of times during burial and metamorphism. Each new phase is formed by the partial or complete dissolution of an earlier dolomite. This continual re-equilibration during burial detracts from the ability of trace elements to indicate depositional conditions and resets the oxygen isotope signature of the dolomite at progressively higher temperatures [17].

There are two types of dolomitization stages in the majority of carbonate platforms: (1) early stage (syn-sedimentary), [18] [19] [20] [21] and (2) postdepositional stage [22] [23]. Finely grained dolomites with fabric-protected dolomitization are dominant in the early stages while medium-large crystalline crystals without fabric protection are dominant in postdepositional stage dolomitization. In this study, both dolomitization stages are observed in Alişandağı dolomites.

\section{Geology of Study Area}

The study area consists of olistoliths in the Bulgurkaya olistostrome (Upper Eocene-Oligocene) in the area called Alişandağı Hill and Misis complex [24]. These olistoliths are formed of Paleozoic-Mesozoic aged and various sizes carbonate and ophiolite blocks in Upper Eocene-Oligocene matrix. All units disappear their initial positions. Demirkazık Formation carbonates and ophiolitic rocks are seen surface at Alişandağ 1 Hill (Figure 2). The gray, medium-thick bedded, fractured, less microfossiliferous, mostly micritic limestone in the region was first named Demirkazık limestone by Yetiş [1] [2]. The Demirkazık formation is deposited in a shallow marine environment that is micritic fabric and its fossils content is Miliolidae, Thaumatoporella and Algea [1] [2] [3]. The Demirkazik formation forming the Mesozoic basement and the Kızıldağ Ofiliyolit are overlain with angular unconformity by the Almacık formation of the Luthetian age. Demirkazık formation in Alişandağı Hill types are limestone, dolomitic limes- 
tone and micritic limestone. The formation consists of dark red, brown, pink, pinkish-yellow, dark gray, black, white and dirty white carbonates. Cracks and folds which are formed as a result of deformations are widely observed in the Demirkazk formation that is locally shown dolomitization.

The Demirkazk formation consists of limestone, dolomite, dolomitic limestone, and calcite dolomite and tectonism is affected all formations in the region. The study area where dolomitization occur in the Alişandağ $\mathrm{Hill}$ is the N-S direction, and its long axis is measured at $1200 \mathrm{~m}$ and its short axis at $650 \mathrm{~m}$. Serpentinized rock units of ophiolitic melange are present in the southern and northeastern parts of Alişandağ ${ }_{1}$ Hill. The calcrete terrace and serpentinized units forming olistolith that appears in the eastern sections of the hill covers Demirkazık formation carbonate with angular unconformity. The region of the hill is covered with alluvium. The serpentinized ophiolitic melange and Demirkazkk formations have a tectonic contact relation and the ophiolitic material is below the carbonates in the south of the study area.

The ophiolitic material and carbonates are near a tectonic contact with the north-south direction in the northeastern part of the hill, the succession of carbonated units coherent with the orientation of the hill is observed in the Alişandağ 1 Hill. The main lithologies that can be distinguished are limestone, dolomitic limestone, calcite dolomite and dolomite and the contacts of these units extend in the North-South direction (Figure 2). The non-dolomitic areas at the mapping region that primary sediments and laminae are preserved with dolomitization. The stratigraphic direction is generally east-west and the slopes are always in the north direction and are around $20^{\circ}-30^{\circ}$.

\section{Material and Method}

Thin sections and polished surfaces were prepared from each of 21 rock samples taken from the Alişandağ 1 Hill. All thin-sections and polished surfaces were examined under an optical microscope. Alizarin Red-S method was made with Dickson [25] method for all calcined polished surfaces and thin sections for calcite-dolomite discrimination. Calcite/dolomite samples were isolated as a result of mineralogical and petrographic examination on thin section and polished section samples.

In the chemical analyzes, 21 samples were determined $\mathrm{MgO}-\mathrm{CaO}$ ratio. Geological map was prepared by field study and $\mathrm{MgO}$ contents of the samples that are known coordinates in the chemical data, and the regions where dolomitization was effective were determined.

\subsection{Petrography}

The samples in the region are classified as limestone (L), fine-grained dolomites (DT-1) and coarse and zoned dolomites (DT-2) based on the thin section. All samples taken from the Demirkazık formation have tectonic micro-fractures. Macro-size cracks which can be distinguished in the polished surface samples are observed (Figure 3(a) Figure 3(b)). Cracks are filled with coarse calcite in 
micritic limestones and (Figure 3(c) Figure $3(d)$ ) the high amplitude stylolites found in some samples are cut tectonic fractures (Figure 3(e) Figure $3(f)$ ).

\subsection{Limestone (L)}

The limestones which are usually micritic, the limestone crystals are euhedral and coarse in the cracks observed and crystal length is $5-15 \mu \mathrm{m}$. Prismatic sparry calcites can grown as marine cement and there are shallow marine foraminifers predominantly of Miliolidae in the limestones (Figure 3(g) Figure $3(\mathrm{~h}))$.

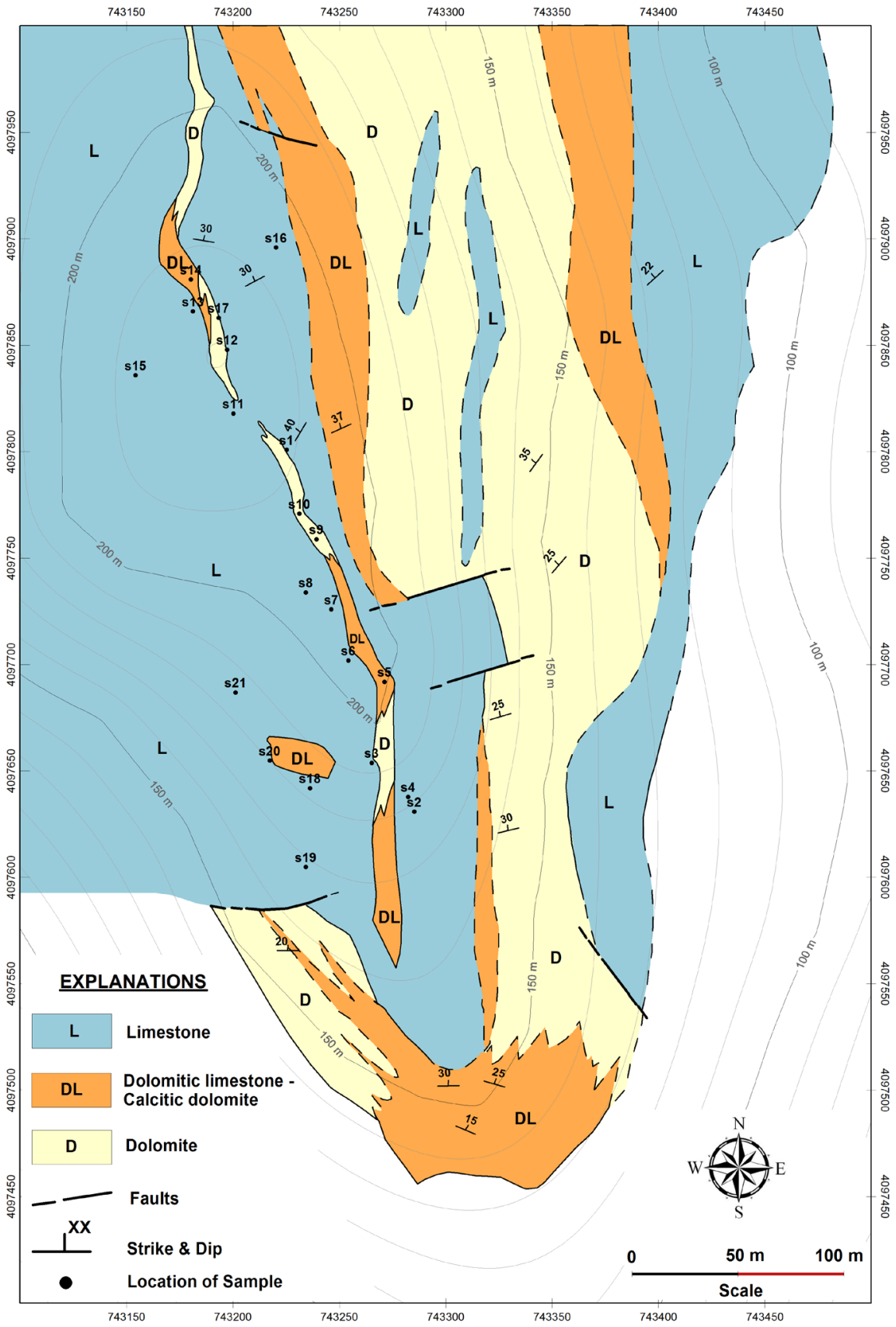

Figure 2. Geologic map of the study area. 


\subsection{Fine Crystalline Dolomite (DT-1)}

These types of dolomite crystals have nonplanar fabrics. They have grown along the cracks in the micritic limestone and are observed of light colored crystalline regions in the micritic limestones. The crystal length $10-25 \mu \mathrm{m}$ and dolomitization fluid does not reach in micritic limestone. They can form with early diagenetic dolomitization and shows well-preserved textures of original sediments.

\subsection{Coarse Crystalline Dolomite (DT-2)}

These dolomite crystals which are usually rombohedral-shaped, have a cloudylike inner zone and outer zone with light colored dolomitic edges (Figure 3(i) Figure3(j)). Zonation is shown in some of the euhedral dolomites. These zone dolomites are observed as cloudy centered, cloudy edges, and clear edges. Dolomite crystals can easily be seen in polished samples and the crystal size is 50 $120 \mu \mathrm{m}$. These crystals which show density around tectonic micro cracks decrease far from the crack. In thin sections where such crystals are present, it is possible to observed stylolite.

\subsection{Chemical Analyzes}

Carbonate rock are divided on the basis of dolomite content into: limestone, dolomitic limestone, calcitic limestone and dolomite [7]. According the chemical analysis on the samples collected from the study area, they are classified into three groups of dolomite (100\% - 90\% dolomite crystal), calcitic dolomite (90\% $50 \%$ dolomite crystal) and dolomitic limestone (50\% - 10\% dolomite crystal,) and $\mathrm{MgCO}_{3}$ ratiooflimestone, dolomitic limestone, calcitic dolomite 0 - 3.36, 12.66 and 32.40 - 37.44 respectively [26], (Figure 4, Table 1).

The CaO-MgO graphs of the samples are given in Figure 5. According to the graphs, the $\mathrm{CaO}$ ratio is $34.39 \%-53.95 \%$ in calcitic dolomites and has low values (Figure 5(a)) and $\mathrm{CaO}$ values in the limestones can reach up to 55.21 (Figure 5(b)). The ratio of $\mathrm{MgO}$ value to calcite dolomite is $17.83 \%$, while that value of limestone is between $0 \%-1.20 \%$.

\section{Discussion}

It is necessary and expected that the contacts between the formation where the general stratigraphic direction is the east and west are also in the east-west direction. However, the contacts of the carbonate units around Alişandağ 1 Hill do not extend in the east-west direction in conformity but on the contrary there is an extension in the north-south direction. The carbonates in the study area were primarily precipitated as limestone $\left(\mathrm{CaCO}_{3}\right)$ and then replaced to dolomite $\left(\mathrm{CaCO}_{3} \cdot \mathrm{MgCO}_{3}\right)$ by burial diagenesis. Dolomitization occurred with late diagenetic stages but all limestone sequence did not replace to dolomite in the Alişandağ 1 Hill region. Dolomitization was more intense in regions where $\mathrm{Ca}$ in the limestone was replaced by $\mathrm{Mg}$ in the direction.

The contacts between dolomite, calcitic dolomite, dolomitic limestone and li- 

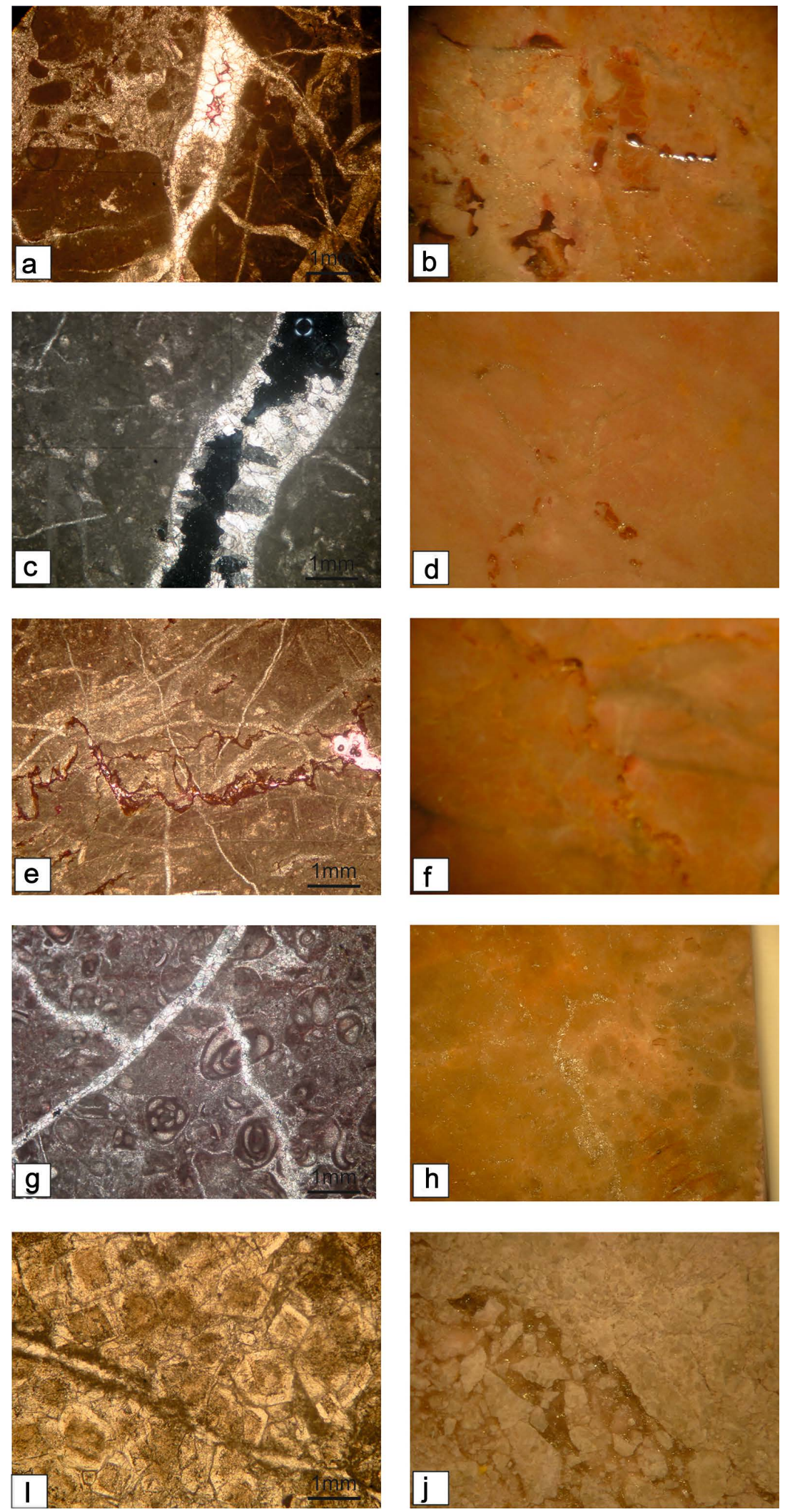

Figure 3. (a) tectonic fractures, (b) macro-sized tectonic fractures, (c) cracks with coarse crystaline, (d) polished surface view of cracks, (e) stylolites, (f) polished surface view of stylolites, (g) Milliolidae, (h) polished surface view of limestone with Milliolidae, (i) coarse cyrstaline dolomites, $(\mathrm{j})$ polished surface view of coarse cyrstaline dolomites. 


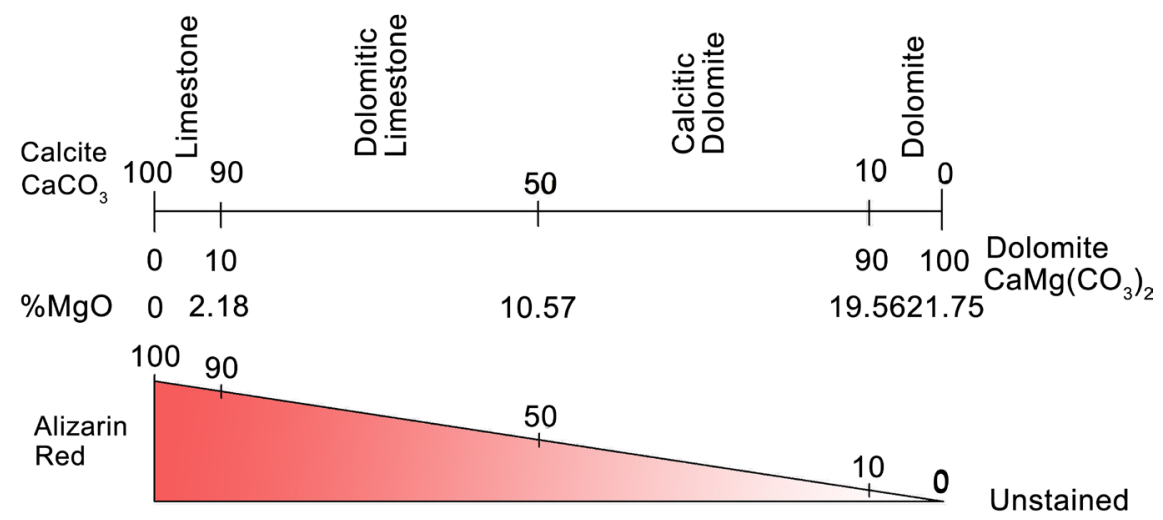

Figure 4. Classification of limestones and dolomites, by calcite-dolomite mineral percentage, $\mathrm{MgO} \%$, and stainability/colour density dispersion (graphed by using Compton [27] classification).

Table 1. Abundance of $\mathrm{CaCO}_{3}, \mathrm{MgCO}_{3}, \mathrm{CaO}$ and $\mathrm{MgO}$ with sample coordinates.

\begin{tabular}{|c|c|c|c|c|c|c|c|c|}
\hline \multirow{2}{*}{ No } & \multicolumn{2}{|c|}{ GPS Coordinates } & \multirow{2}{*}{ Sample Name } & \multirow{2}{*}{$\mathrm{CaCO}_{3} \%$} & \multirow{2}{*}{$\mathrm{MgCO}_{3} \%$} & \multirow{2}{*}{$\mathrm{CaO} \%$} & \multirow{2}{*}{$\mathrm{MgO} \%$} & \multirow{2}{*}{ Ca:Mg } \\
\hline & Latitude & Longitude & & & & & & \\
\hline s1 & 743225 & 4097801 & $\begin{array}{l}\text { Dolomitic } \\
\text { limestone }\end{array}$ & 85.93 & 12.66 & 48.12 & 6.03 & 9.50 \\
\hline $\mathrm{s} 2$ & 743285 & 4097631 & Limestone & 96.86 & 1.68 & 54.24 & 0.80 & 80.72 \\
\hline s3 & 743265 & 4097654 & Limestone & 98.59 & 0.84 & 55.21 & 0.40 & 164.32 \\
\hline s4 & 743282 & 4097638 & Limestone & 97.25 & 0.00 & 54.46 & 0.00 & \\
\hline s5 & 743271 & 4097692 & Calcitic dolomite & 61.98 & 36.35 & 34.71 & 17.31 & 2.39 \\
\hline s6 & 743254 & 4097702 & Limestone & 95.52 & 0.86 & 53.49 & 0.41 & 155.50 \\
\hline s7 & 743246 & 4097726 & Limestone & 94.43 & 1.68 & 52.88 & 0.80 & 78.69 \\
\hline s8 & 743234 & 4097734 & Limestone & 97.02 & 0.00 & 54.33 & 0.00 & \\
\hline s9 & 743239 & 4097759 & Calcitic dolomite & 64.55 & 32.40 & 36.15 & 15.43 & 2.79 \\
\hline s10 & 743231 & 4097771 & Limestone & 97.66 & 0.00 & 54.69 & 0.00 & \\
\hline s11 & 743200 & 4097818 & Limestone & 97.77 & 0.00 & 54.75 & 0.00 & \\
\hline s12 & 743197 & 4097848 & Limestone & 96.36 & 3.36 & 53.96 & 1.60 & 40.15 \\
\hline s13 & 743181 & 4097866 & Limestone & 97.77 & 1.70 & 54.75 & 0.81 & 80.52 \\
\hline s14 & 743180 & 4097881 & Calcitic dolomite & 96.36 & 33.94 & 53.96 & 16.16 & 3.97 \\
\hline s15 & 43154 & 4097836 & Limestone & 97.95 & 1.70 & 54.85 & 0.81 & 80.66 \\
\hline s16 & 743220 & 4097896 & Limestone & 98.52 & 0.84 & 55.17 & 0.40 & 164.20 \\
\hline s17 & 743193 & 4097863 & Limestone & 98.55 & 0.84 & 55.19 & 0.40 & 164.25 \\
\hline s18 & 743236 & 4097642 & Limestone & 97.50 & 0.86 & 54.60 & 0.41 & 158.72 \\
\hline s19 & 743234 & 4097605 & Limestone & 96.93 & 2.54 & 54.28 & 1.21 & 53.43 \\
\hline s20 & 743217 & 4097655 & Calcitic dolomite & 61.41 & 37.44 & 34.39 & 17.83 & 2.30 \\
\hline s21 & 743201 & 4097687 & Limestone & 94.66 & 2.52 & 53.01 & 1.20 & 52.59 \\
\hline
\end{tabular}

mestone are the correlations between the mineral calcite and dolomite via \% $\mathrm{MgO}$ values. The extensions of these contacts on the surface around Alişandağ 1 Hill are approximately in the north-south direction. The western of the hill has a lenght of $500 \mathrm{~m}$ in the northwest-southwest direction, approximately north- 
south. The distance varies from 0 to $12 \mathrm{~m}$. The western of the hill is mainly dolomite and calcitic dolomite and lateral transitions.

The contact between the litology was investigated by separating limestone, dolomite, calcitic dolomite, dolomitic limestone and three formed rock units as shown in the geological map (Figure 2) related to the Mesozoic carbonate $\mathrm{Mg}$ content of the mineral in Demirkazık formation Alişandağ 1 Hill. Transitions of these units on the map is gradual and dolomite is occurred in the center of limestone or dolomitic limestone. Dolomitization along a linear line is observed in the west whereas calcite dolomite is dominant in the west and south of the study area where dolomitization is partially in .The contacts between these units are also completely irregular with the reason for the formation of late burial diagenesis, transitions in all directions.

Two dolomite types are petrographically determined. TD-1 is fine crystalline dolomites with good fabric preservation and form at early stage (syn-sedimentary) and TD-2 is crystalline dolomites with fabric destruction and form at
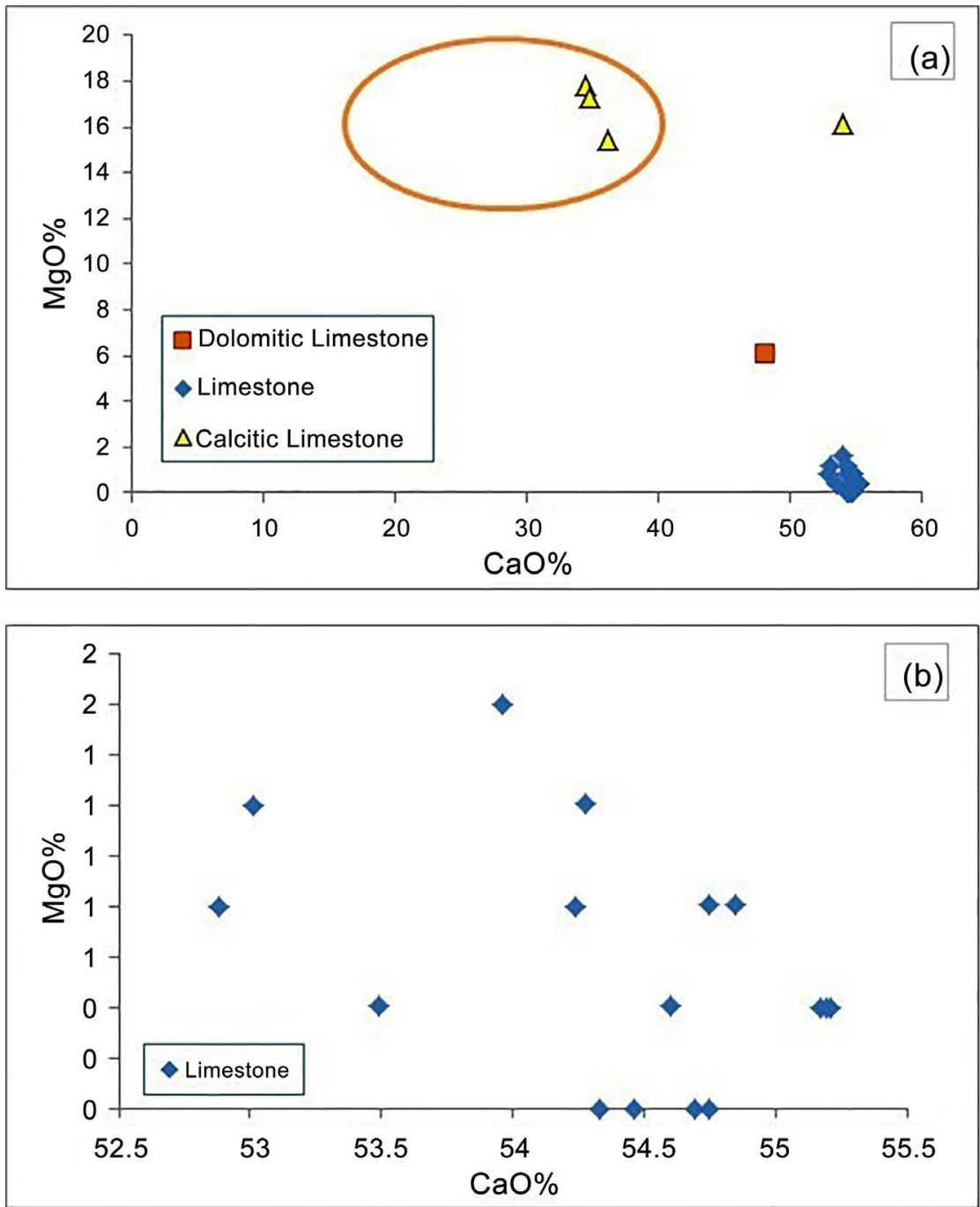

Figure 5. CaO-MgO plots of the samples (a) limestone-dolomitic limestone and calcitic dolomite chart, (b) limestone chart. 
postdepositional stage at Alişandağı Hill.Tectonic micro-fractures, macrosize cracks, late diagenetic stylolites are present at calcitic dolomites and limestones.

\section{Results}

According to the fossil content in the limestones of the Demirkazık formation, the deposited formation is a shallow marine environment and the micritic limestone suggests that it has formed in a low-energy environment. However, the existence of stylolites after the sedimentation and the crossing of the initial structures reveal the burial dolomitization.

Dolomitization stages can be examined in two groups as early diagenetic and late diagenetic (subsurface burial dolomitization). The dolomites formed in the early diagenetic stage were dolomitized immediately after sedimentation by limestone replacement, and fine-grained TD-1 dolomites were formed after dolomitization.

The late diagenetic dolomites were formed by the replacement of limestone of Mg-rich waters after sedimentation. The dolomites observed in the AlişandağıTepe, Ceyhan-Adana region were formed in the early and late diagenetic stages, and the evidence of dolomitization due to pressure changes in the TD-2 dolomites is evidence of late diagenetic.

There are three groups of carbonate in study area; dolomite, calcitic dolomite and dolomitic limestone. The rate of dolomitization is very variable and at the fracture regions, the $\mathrm{Mg}$ ratio increases, indicating that tectonism is the cause of dolomitization.

Adana regional dolomites are associated with dolomites formed by mid-late diagenetic replacement. It comes into play with the replacement of primary limestones. In this type of replacement, usually the original textures are not protected. TD-1 type dolomite is similar to that described by Sibley and Gregg [28] as xenotopic dolomite. Xenotopic texture is formed by the neomorphic recrystallization of the previous dolomite or dolomite replacement of the limestones at high temperatures [29]. Folk [30] described an irregularly shaped dolomite from several stratigraphic areas. In non-planar-a dolomite in buried environments, it was formed by the replacement of primary limestones.

Dolomitization occurred partially in the limestone formation during the late diagenetic phase. Migration of magnesium-rich waters, is formed by the compression of pelagic muds in the dolomitization of burials.

\section{References}

[1] Yetis, C. (1978a) Çamardı (Niğde)

YakınveUzakDolayınınJeolojiİncelemesiveEcemişYarılımKuşağınınMadenBoğazıKamışlıArasındakiÖzellikleri [Geology of the Çamardı (Niğde) Region and the Characteristics of the Ecemiş Fault Zone between MadenBoşaz and Kamışli], PhD thesis, İstanbul University, 164 p., Turkey, [in Turkish].

[2] Yetis, C. (1978 b) Geology of the Çamardı (Niğde) Region and the Characteristics of the Ecemiş Fault Zone Between MadenBoğazı and Kamışlı. Revue De La Faculte Des Sciences, Serie B, Tone 43, 41-61, İstanbul. 
[3] Yetis, C. and Demirkol, C. (1986) Adana BaseniBatıKesimininDetayJeolojikEtüdü [Detailed Geological Investigation of Western Adana Basin]. Mineral Research and Exploration Institute (MTA) of Turkey, Report No. 8037 [unpublished, in Turkish].

[4] Land, L.S. (1985) The Origin of Massive Dolomite. Journal of Geological Education, 33, 112-125.

[5] Morrow, D.W. (1982) Diagenesis, 2. Dolomite-Part 2: Dolomitization Models and Ancient Dolostones. Geoscience Canada, 9, 95-107.

[6] Tucker, M. and Wright, V.P. (1990) Carbonate Sedimentology. Blackwell Science, Oxford, 482 p. https://doi.org/10.1002/9781444314175

[7] Tucker, M.E. (2001) Sedimentary Petrology. 3rd Edition, Blackwell Science, Oxford, $262 \mathrm{p}$.

[8] Humphrey, J.D. (1988) Late Pleistocene Mixing Zone Dolomitization, Southeastern Barbados, West Indies. Sedimentology, 35, 327-348. https://doi.org/10.1111/j.1365-3091.1988.tb00951.x

[9] Luczaj, J.A. (2006) Evidence against the Dorag (Mixing-Zone) Model for Dolomitization along the Wisconsin Arch-A Case for Hydrothermal Diagenesis. AAPG Bulletin, 90, 1719-1738. https://doi.org/10.1306/01130605077

[10] Ward, W.C. and Halley, R.B. (1985) Dolomitization in a Mixing Zone of NearSeawater Composition, Late Pleistocene, Northeastern Yucatan Peninsula. Journal of Sedimentary Research, 55, 407-420.

[11] Patterson, R.J. and Kinsman, D.J.J. (1982) Formation of Diagenetic Dolomite in Coastal Sabkha along Arabian (Persian) Gulf. AAPG Bulletin, 66, 28-43.

[12] Adams, J.E. and Rhodes, M.L. (1960) Dolomitization by Seepage Refluxion. AAPG Bulletin, 44, 1912-1920.

[13] Melim, L.A. and Scholle, P.A. (2002) Dolomitization of the Capitan Formation Forereef Facies (Permian, West Texas and New Mexico): Seepage Reflux Revisited. Sedimentology, 49, 1207-1227. https://doi.org/10.1046/j.1365-3091.2002.00492.x

[14] Mattes, B.W. and Mountjoy, E.W. (1980) Burial Dolomitization of the Upper Devonianmiette Buildup. Jasper National Park, Alberta.

[15] Zenger, D.H. (1983) Burial Dolomitization in the Lost Burro Formation (Devonian), East-Central California, and the Significance of Late Diagenetic Dolomitization. Geology, 11, 519-522. https://doi.org/10.1130/0091-7613(1983)11<519:BDITLB>2.0.CO;2

[16] Machel, H.G. (2004) Concepts and Models of Dolomitization: A Critical Reappraisal. Geological Society of London Special Publication, 235, 7-63. https://doi.org/10.1144/GSL.SP.2004.235.01.02

[17] Warren, J. (2000) Dolomite: Occurrence, Evolution and Economically Important Associations. Earth-Science Reviews, 52, 1-81. https://doi.org/10.1016/S0012-8252(00)00022-2

[18] Balog, A., Read, F. and Haas, J. (1999) Climate-Controlled Early Dolomite, Late Triassic Cyclic Platform Carbonates, Hungary. Journal of Sedimentary Research, 69, 267-282. https://doi.org/10.2110/jsr.69.267

[19] Haas, J. and Demeny, A. (2002) Earlydolomitisation of Late Triassic Platform Carbonates in the Transdanubian Range (Hungary). Sedimentary Geology, 151, 225242. https://doi.org/10.1016/S0037-0738(01)00259-7

[20] Qing, H. (1998) Petrography and Geochemistry of Early-Stage, Fine- and Medium-Crystalline Dolomites in the Middle Devonian Presqu'ile Barrier at Pine Point, Canada. Sedimentology, 45, 433-446.

https://doi.org/10.1046/j.1365-3091.1998.0154f.x 
[21] Yoo, C.M. and Lee, Y.I. (1998) Origin and Modification of Early Dolomites in Cyclic Shallow Platform Carbonates, Yeongheung Formation (Middle Ordovician), Korea. Sedimentary Geology, 118, 141-157. https://doi.org/10.1016/S0037-0738(98)00010-4

[22] Eren, M. (1993) Burial Dolomitization within Atoka Carbonates. Giornale di Geologia, 55, 171-176.

[23] Eren, M., Yeşilot Kaplan, M. and Kadir, S. (2007) Petrography, Geochemistry and Origin of Lower Liassic Dolomites in the Aydincik Area, Mersin, Southern Turkey. Turkish Journal of Earth Sciences, 16, 339-362.

[24] Kozlu, H. (1997) Tectono-Stratigraphic Units of the Neogene Basins (Iskenderun, Misis-Andirin) and Their Tectonic Evolution in the Eastern Mediterranean Region. Unpublished PhD Thesis, Natural Science Institute, Cukurova University Adana Turkey. (In Turkish)

[25] Dickson, J.A.D. (1965) A Modified Staining Technique for Carbonates in Thin Section. Nature, 205, 587-587.

[26] Yetis, C., Mert, B.A. and Anıl, M. (2006) Geological Mapping Based on Diagenetic Dolomite-Calcite Determinations: A Case Study, Alişandağ (Ceyhan-Adana)). 59th Geological Congress of Turkey, Turkey, 164-166.

[27] Compton, R.R. (1962) Manual of Field Geology. John Wiley \& Sons, New York, 378 p.

[28] Sibley, D.F. and Gregg, J.M. (1987) Classification of Dolomite Rock Textures. Journal of Sedimentary Petrology, 57, 967-975.

[29] Gregg, J.M. and Sibley, D.F. (1984) Epigenetic Dolomitization and the Origin of Xenotopic Dolomite Texture. Journal of Sedimentary Petrology, 53, 908-931.

[30] Folk, R.L. (1959) Practical Petrographic Classification of Limestones. AAPG Bulletin, 43, 1-38.

Submit or recommend next manuscript to SCIRP and we will provide best service for you:

Accepting pre-submission inquiries through Email, Facebook, LinkedIn, Twitter, etc. A wide selection of journals (inclusive of 9 subjects, more than 200 journals)

Providing 24-hour high-quality service

User-friendly online submission system

Fair and swift peer-review system

Efficient typesetting and proofreading procedure

Display of the result of downloads and visits, as well as the number of cited articles

Maximum dissemination of your research work

Submit your manuscript at: http://papersubmission.scirp.org/

Or contact gep@scirp.org 